\title{
Improving Public Welfare or Burdening the State: Indonesia's New Autonomous Region in Decentralization Era
}

\author{
Hardi Warsono; Yuwanto \\ Public Administration Doctoral Program, Faculty of Social and Political Science \\ Diponegoro University \\ Semarang, Indonesia \\ (Office Email:prodidap@gmail.com)
}

\begin{abstract}
Since Indonesian Law No. 22 Year 1999 on Regional Government having been enacted, there are a massive regional expansions (also known as a "region splitting") in Indonesia. Within a decade (1999-2009) there are new 7 provinces, 164 regencies and 34 cities existed, bringing the total increase of 205 new autonomous regions. The evaluation result shows that not all goals of establishing a new autonomous region are reached. Supposedly the formation of new areas as a form of regions can improve people's welfare, accelerate an equitable distribution of development, improve the quality of public services, enhance the competitiveness of the region and establish good governance in the region. The development of new autonomous regions often does not reveal the phenomenon on purpose, but instead of forming a new dependency on the new autonomous regions to the central government. This fact leads to the mechanism of forming new autonomous regions reorganized by Law No. 23 of 2014.
\end{abstract}

Keywords-regional expansion; new autonomous regions; public welfare

\section{INTRODUCTION}

The regional autonomy in Indonesia given by the government in order that development can be more effective, the quality of public services is increasing and the welfare of the people as the ultimate goal can be materialized. As the dynamics of local politics is getting stronger, narrowing the objectives of regional autonomy has occurs only toward "the establishment of regional" than necessary "regional arrangement." In the arrangement of the area includes the following activities: the establishment, merger, adjustment and evaluation capabilities and fostering autonomous regions (Ministry of Home Affairs, 2010).

It has been found that many formations of new autonomous regions tends to satisfy the interests of the local elite group for the sake of power, without considering more long-term interest to materialize an equitable distribution of development and public welfare, thus only making the new autonomous regions cannot be develop properly and independently.

\section{Theoretical Framework AND Method}

This study employs Indonesia's decentralization as a case study. Accordingly, it uses several basic questions as a framework namely: how to evaluate the establishment of new autonomous regions, what factors encourage the formation of new regions, and how is the revision of the mechanism of formation of new autonomous regions implemented. Methodologically, in line with Yin (1995), case study employed as the data collecting technique to achieve the research objectives. The advantage of case study is on the research questions of "how" and "why" that leads to a set of contemporary events, where the researcher does not have the opportunity to control the events. Data is collected by revealing phenomena that Become research focuses. It is because the research is using triangulation technique. Result and Discuss.

\section{CURRENT FINDINGS}

\section{A. Evaluation of the Establishment of New Autonomous Region}

The Indonesian Ministry of Home Affair formed a team that is tasked with evaluating new autonomous regions. If the results of the evaluation show that the new autonomous regions are not able to improve the public welfare and not be able to push the equity in development, the new autonomous regions can be returned to their parent regions. This assessment team is working with a number of indicators which are focused on the region's ability to produce local revenues as a source of financing of the regional administration. The assessment will be more comprehensive if the focus of the ability to generate the local revenue is synergized with the regional capabilities in improving public welfare and bureaucratic competence in governance more broadly.

The results of the evaluation conducted by the Ministry of Home Affairs shows that in general the regional growth has not been able to encourage an equitable distribution of development and welfare of the community, but (the new autonomous regions) are still much dependent on the central government in financing their regions. The condition is caused by the low capacity of the regions in the search for their own 
sources of revenue. The second finding indicates that the goals of autonomy to shorten the span of control of governance have not been proven yet because there are still many affairs of the new autonomous regions handled by the central government. Evaluation of the Ministry of Home Affairs shows that $80 \%$ of new autonomous regions are performing poorly, even some of them are declared failed. This failure is mainly caused by the unprepared region at the beginning of the transition period, especially in the first 3 years.

\section{B. Supporting Factors in the Formation of New Autonomous Region}

Proposed establishment of new autonomous regions is generally based on political interests reinforced by certain parties with the purpose of obtaining power and to get subsidies from the central government. The other factor leading to the formation of new autonomous regions is the desire of making public service closer to the community. With the far location of the capital, people in some areas find it difficult to access services provided by local governments.

The formation of new autonomous regions is not only related to the division of powers and the provision of subsidies from the central government, but also about the future of a region including the natural potential. When the consideration is based only on short-term interests, the new autonomous regions will not be able to advance and to be independent. The criteria "developed" include: per capita income, gross domestic income, human development index, public services, regional competitiveness in the economy and social resilience. This condition is a comparison between before and after becoming an autonomous region. Meanwhile, independent is defined as the ability to control and manage its own country, to finance part of the spending areas from the development of the region potential (Wasistiono, 2012).

\section{Mechanism of Forming New Autonomous Region}

Under the new policy, the establishment of new autonomous regions do not necessarily apply when an area has been set to become the new autonomous ones, but through several stages as a preparatory region. If the evaluation results in the region of preparation prove unable to encourage equitable development and improve the public welfare, central government can restore the region to its covering region.

Aims of the regions structuring policy in Indonesia are to improve the effectiveness of local governance, accelerate the improvement of public welfare, accelerate the improvement of the quality of public services, improve the quality of governance, enhance the regional competitiveness and maintain the uniqueness of local customs, traditions and culture of the region.

The scope of the region structuring in Indonesia comprise the regional division and merging of regions. Regional expansion (in the case of "region splitting" plan of Brebes Regency in Central Java Province) was running slow because according to regulations (Act No. 23 of 2014 on Regional Government) it must pass through the stages namely new preparation region and then set as the new autonomous region. To pass the preparatory stage requires a long way including the assessment of regional divisions related to the basic requirements related to the three aspects of territorial and regional capacities and the fulfillment of administrative requirements, namely the approval of the relevant parties.

Firstly, the requirement includes: area, population minimal, boundaries, area coverage (for new province at least 5 regencies, for regency at least 5 districts and to the city at least 4 sub-districts), and limit minimal age of the origin regions (provinces 10 years, regencies/cities and sub-districts 7 years 5 years consecutively).

Secondly, the region capacity means ability to thrive in materializing the public welfare. This region capacity covers aspects such as: geography, demographics, security, social policy, customs and traditions, economic potential, local finance and local governance capabilities.

Lastly, the administrative requirements are the approval of the relevant parties. The development of the province needs the approval from the City or Regency Regional Council (Local Parliament) of the new development regions to be its area and approval of the provincial parliament with the governor of the province. Similarly for new autonomous regions, the level of regency/city requires similar approval on its level.

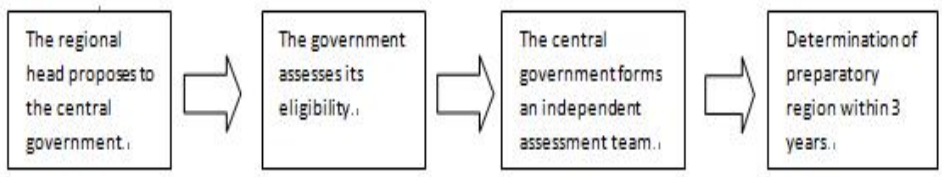

Figure 1. The mechanism for determining the preparatory region

This preparatory region will be evaluated within three years; and if the region does not meet the requirements, it will be returned to its origin region. However, if eligible, it can be approved as a new autonomous region. Preparatory region according to the "Big Design of Region Formation" is part of the autonomous region specially prepared to be a new autonomous region, by providing authority to run the government under the guidance and responsibility of the autonomous origin region.

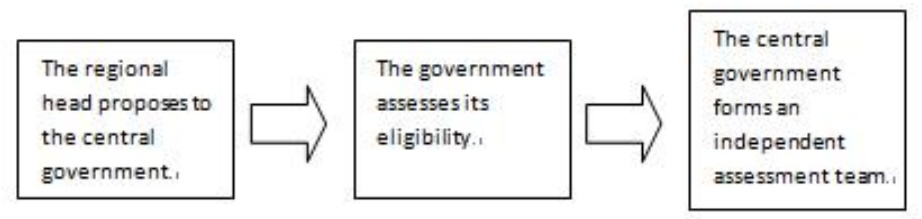

Figure 2. Formation Mechanism of New Autonomous Region

The mechanism for forming an autonomous region as mentioned above is in a generally accepted standard mechanism for the establishment of new autonomous regions in Indonesia, but for a certain circumstances, it can be excluded for the formation regions of the state border, offshore islands and on studies conducted by the government.

Thus, the region formations are not going to be trapped by the desire of local politicians solely for the sake of some elite group desire who wants to get power from the formation of the region, but through long stages to ensure the benefit of new region for the welfare of the people. In addition to the improvements in the regulatory side, the government has 
formed a great design for region arrangement in the year 20102025. This big design for the region arrangement is primarily intended to change the mindset that regional autonomy merely "local establishment" to "regional arrangement." This big design also requires the preparation stage which is a critical stage of the formation of new autonomous regions.

\section{CONCLUSION}

Arranging region is not merely making an expansion or splitting a region, but it is much broader sense related to mergers, adjustment and evaluation of capabilities and fostering autonomous regions. Evaluation of a preparation region is a strategic activity in order to determine whether the preparatory region will be sustained as a new autonomous region or returned to its origin region. Therefore, the indicator of evaluation should be comprehensive and is not just limited to the ability of the preparatory region to generate their own revenue but also related to whether the implementation of the preparatory region can encourage an equitable distribution of development and the welfare of society as well as related indicators of good governance.

\section{ACKNOWLEDGMENT}

This paper is part of research on Evaluation of The New Autonomous Regions in Indonesia. We would like to thank all of the parties involved and contributed, especially Ministry of Home Affairs and Brebes Regency among others, including to the anonymous readers who make meaningful contribution in the early draft.

\section{REFERENCES}

[1] Albrow, M. (2005). Birokrasi. Tiara Wacana Jakarta.

[2] Charles, H., \& Anne, D. (Eds.). (1994). The post bureaucratic organization, new perspective on organization change. SagePublication, Thousand Oaks, CA.

[3] Cheema, Shabbir, \& Dennis, R. (1983). Decentralization and development. Baverly Hills, CA: Sage publications.

[4] Djohan, D. (2002). Fenomena etnosentrisme dalam penyelenggaraan otonomi daerah (Ethnocentrisms phenomenon in regional autonomy implementation). A paper in workshop Desentralisasi, Demokratisasi, dan Akuntabilitas Pemerintahan Daerah (Decentralization, Democratization and Government Accountability), Diponegoro University, Semarang, Indonesia.

[5] Fukuyama, F. (1995). Trust: The social virtues and the creation of prosperity. New York, NY: The Free Press.

[6] Henry, N. (1995). Public administration and public affairs (6th ed.). Englewood Cliffs, NJ: Prentice-Hall.

[7] Jenkins, W. O. (2006). Collaboration over adaptation. Public Administration Review, 66(3), 319-321.

[8] McGuire, M. (2006a). Intergovernmental management: A view from the bottom. Public Administration Review, 66(5), pp. 677-679.

[9] Patterson, D. A. (2008). Intergovernmental cooperation. Albany, NY: New York State Department of State Division of Local Government Services.

[10] Rendell, E. G., \& Yablonsky, D. (2006). Intergovernmental cooperation. Handbook. Harrisburg, Pennsylvania: Department of Community and Economic Development.

[11] Robert, K. Y. (1995). Studi kasus, desain dan methode (Case studies, design and method). PT. Raja Grafindo, Jakarta.

[12] Rouke, F. E. (1965). Bureaucratic power in national politics. Little Brown, Boston, MA.

[13] Thomson, A. M., \& James, L. P. (2006). Collaboration process: Inside the black box. Public Administration Review, 66, 20

[14] Wasistiono, Sadu, dkk. (2012). Parameter Daerah Persiapan: Penjelasan Teknis Pembentukan Daerah Otonom Baru dalam Desain Penataan Daerah, Jakarta, Kemitraan Bagi Pembaruan Tata Pemerintahan. 